The investigation is being continued for the purpose of finding the stereochemistry of the molecule, bondlengths and angles, disposition of hydrogen bonds, etc., in more detail, and when this has been done a full description of the structure and the method of structure analysis employed will be published by one of us (M. M. W.).

D. M. Brown

G. D. FASMAN

D. I. Magrath

A. R. TODD

University Chemical Laboratory, Cambridge.

W. Cochran

Cavendish Laboratory, Cambridge. Nov. 4.

M. M. WOOLFSON

${ }^{1}$ Brown, D. M., and Todd, A. R., J. Chem. Soc., 2040 (1953). Brown, D. M., Heppel, L. A., and Hilmoe, R. S., J. Chem. Soc. (in the ${ }^{2}$ Brown, D. M., and Todd, A. R., J. Chem. Soc., 52 (1952).

${ }^{3}$ Carter, C. E., and Cohn, W. E., Fed. Proc., 8, 190 (1949) and subsequent papers.

4 Brown, D. M., and Todd, A. R., J. Chem. Soc., 44 (1952).

${ }^{5}$ Loring, H. S., Hammell, M. L., Levy, L. W., and Bortner, H. W., J. Biol. Chem., 196, 821 (1952). Cavalieri, L. F., J. Amer. Chem. Soc., 74, 5804 (1952). Fox, J. J., Cavalieri, L. K., and Chang, N. Todd, A. R., J. Chem. Soc. (in the press).

${ }^{6}$ Brown D. M. Dekker, C. A., and Todd, A. R., J. Chem. Soc., 2715 (1952).

' Khym, J. X., Doherty, D. G., Volkin, E., and Cohn, W. E., J. Amer. Chem. Soc. 75,1262 (1953).

${ }^{8}$ Brown, D. M., Magrath, D. I., and Todd, A. R., J. Chem. Soc. (in the press).

'Corby, N. S., Kenner, G. W., and Todd, A. R., J. Chem. Soc., 3669 (1952)

\section{Conversion of $\delta$-Aminolævulinic Acid to Porphobilinogen in a Tissue System}

WE showed recently that porphobilinogen is a highly specific precursor of porphyrins, and Shemin and Russell ${ }^{2}$ have presented evidence that $\delta$-aminolævulinic acid is a specific precursor of hæm. Shemin and Russell's finding has been confirmed independently in our system (cf. Neuberger and $\mathrm{Scott}^{3}$ ) to the extent that, on incubation with a chicken red cell hæmolysate,$\delta$-aminolævulinic acid is converted to uro-, copro- and protoporphyrins. The yield of each of these porphyrins from $\delta$-aminolævulinic acid was, moreover, identical to that ${ }^{1}$ from an equivalent amount of porphobilinogen. The structure of porphobilinogen ${ }^{5}$ suggests that this compound could be formed by the condensation of two molecules of $\delta$-aminolæuvulinic acid (see also refs. 2 and 3 ), and the equivalence of the two compounds with respect to porphyrin formation may be taken as support for this idea. We now present evidence indicating the occurrence of such a condensation in the chicken red cell hæmolysate.

When $\delta$-aminolævulinic acid is incubated with the hæmolysate, a substance reacting positively with Ehrlich's reagent can be shown to accumulate. After paper chromatography of this material in either a butanol - acetic acid or a phenol-ammonia solvent system $^{6}$, only one spot reacting with Ehrlich's reagent was found. With both solvent systems the $R_{F}$ values and appearance of the spots were identical to those obtained with a crystalline sample of porphobilinogen hydrochloride. The material was concentrated $^{b}$; on heating the resulting solution in acida $^{8}$ a porphyrin was obtained which, on paper

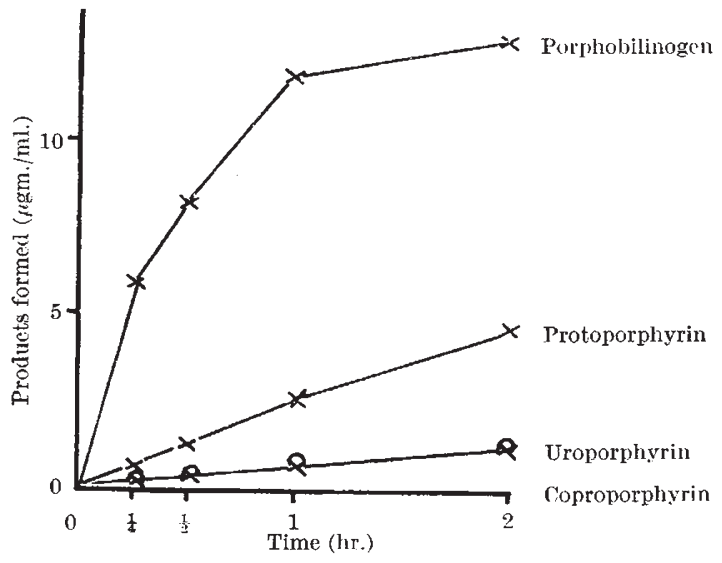

Fig. 1. Conversion of $\delta$-aminolævulinic acid to porphobilinogen and porphyrins. Hæmolysate (ref. 4) incubated at $38^{\circ}$, with shaking in air. $\delta$-Aminolævulinic acid added, $47 \mu \mathrm{gm} . / \mathrm{ml}$

chromatograms, behaved identically to the uroporphyrin obtained in the same way from pure porphobilinogen ${ }^{5}$. Furthermore, conversion to substances behaving on paper chromatograms as the acetyl and lactam derivatives ${ }^{5}$ of porphobilinogen was demonstrated. We therefore believe that the material formed from $\delta$-aminolævulinic acid in the hæmolysate is, in fact, porphobilinogen.

The accumulation of porphobilinogen, uro-, coproand protoporphyrins in a hæmolysate incubated with $\delta$-aminolævulinic acid is illustrated in Fig. 1. No trace of these substances was formed if the hæmolysate was boiled prior to the addition of $\delta$-aminolævulinic acid.

We are continuing our study of the interconversions of the porphyrins and their precursors, and, in particular, the relation of these processes to the biosynthesis of hæm.

We thank Mr. J. J. Scott and Dr. A. Neuberger for a gift of $\delta$-aminolævulinic acid, Miss A. Benson for her assistance and Prof. C. Rimington for his continuing support.

E. I. B. Dresel J. E. FALK

Nuffield Unit for the Investigation of Pyrrole Pigment Metabolism,

Department of Chemical Pathology, University College Hospital Medical School, London, W.C.1.

$$
\text { Dec. } 1 \text {. }
$$

1 Falk, J. E., Dresel, E. I. B., and Rimington, C., Nature, 172, 292 (1953).

2 Themin, D, and Russell, C. S. J. Amer. Chem. Soc., 75, 4873 (1953).

${ }^{3}$ Neuberger, A., and Scott, J. J., [Nature, 172, 1093 (1953)].

${ }_{4}$ Dresel, E. I. B., and Falk, J. F., Biochem. J. (in the press).

${ }_{5}$ Cookson, G. H., and Rimington, C., Nature, 171, 875 (1953). Cookson, G. H., Nature, 172, 457 (1953).

6 Westall, R. G., Nature, 170, 614 (1952).

\section{Chromatographic Behaviour of Intermedin as determined by in vitro Assays}

PAPER chromatography was used in a recent attempt to obtain purified intermedin, the melanophorotropic hormone of the pituitary intermediate lobe. This communication is submitted because of the new assays employed and the interesting chromatographic behaviour of intermedin activity.

Powdered hog posterior pituitary glands were treated by the method of Landgrebe, Reid and 